\title{
Intestinal Atresia: Twenty Years of Experience at a Reference Hospital
}

\author{
Intestinal Atrezi: Referans Bir Hastanenin Yirmi Yıllık Deneyimi
}

\author{
(D) Mehmet Saraç¹, (D) Tugay Tartar¹, (D) Ünal Bakal1, (D) Mustafa Aydın², (D) Ibrahim Akdeniz¹, (D) Ahmet Kazez¹ \\ ${ }^{1}$ Fırat University Faculty of Medicine, Department of Pediatric Surgery, Elazığ, Turkey \\ 2Fırat University Faculty of Medicine, Department of Neonatology, Elazığ, Turkey
}

\begin{abstract}
Introduction: The aim of this study was to reveal the factors that affect the clinical outcomes of patients undergoing surgery in our university hospital for intestinal atresia (IA) and to share our experience.

Methods: We analyzed data from 74 newborns with IA who underwent surgical treatment between January 1997 and December 2016.

Results: The study population consisted of 40 female and 34 male newborns with a mean age at diagnosis of $6.4 \pm 8.3$ days. The mean birth weight was $2.3 \pm 0.6 \mathrm{~kg}$, the mean gestational age was $35.6 \pm 2.8$ weeks, the mean maternal age was $28.9 \pm 6.1$ years, and the mean hospitalization time was $24.5 \pm 25.3$ days. Duodenal atresia was the most common diagnosis $(n=31,42 \%)$ and colonic atresia the least common $(n=2,3 \%)$. The longest and shortest mean hospital stays occurred in patients with jejunal (32.8 \pm 41.6 days) and those with colonic ( $8 \pm 0$ days) atresia, respectively. Although the survival rates were low in newborns with either intestinal or duodenal atresia (80\% or $81 \%$, respectively), all patients with pyloric or colonic atresia survived. Of the patients who died, $82 \%(9 / 11)$ had additional congenital abnormalities $\left(X^{2}=8.461, p=0.004\right)$, which included major cardiac defects $(n=3)$, Down syndrome $(n=2)$, biliary atresia $(n=1)$, esophageal atresia + tracheoesophageal fistula + anal atresia + tracheal atresia $(n=1)$, esophageal atresia + tracheoesophageal fistula $(n=1)$, and microcephaly $(n=1)$. The mean hospital stay of patients with or without additional abnormalities was $26.4 \pm 21.4$ or $23.04 \pm 28.04$ days, respectively $(p=0.207)$.
\end{abstract}

Conclusion: Among newborns with IA, duodenal atresia was the most common diagnosis and colonic atresia the least common. Additional congenital abnormalities negatively affect the hospital stay and mortality rate of newborns with IA.

Keywords: Intestinal atresia, surgical treatment, hospital stay, mortality, newborn

\section{öZ}

Amaç: Bu çalıșmada, bir üniversite hastanesinde intestinal atrezi (IA) endikasyonu ile ameliyat edilen hastaların klinik sonuçlarına etkili olan faktörleri ortaya koymak ve deneyimlerimizi paylaşmak amaçlanmıștır.

Yöntemler: Ocak 1997-Aralık 2016 tarihleri arasında cerrahi tedavi uygulanan 74 İA'lı yenidoğan olgu çalışmaya alındı.

Bulgular: Çalıșma popülasyonu, tanı anındaki ortalama yașı $6,4 \pm 8,3$ gün olan 40 kız ve 34 erkek yenidoğandan oluşuyordu.

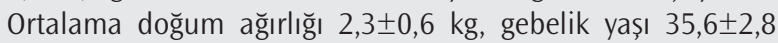
hafta, anne yașı $28,9 \pm 6,1$ yıl ve hastanede kalış süresi $24,5 \pm 25,3$ gündü. En fazla duodenal atrezi $(n=31, \% 42)$, en az ise kolon atrezisi $(n=2, \% 3)$ görüldü. En uzun ve en kısa ortalama hastanede kalış süreleri sırasıyla jejunal atrezili (32,8 $\pm 41,6$ gün) ve kolonik atrezili (8 80 gün) olgularda saptandı. Sağkalım oranları multipl IA'da ve duodenal atrezide düşük (sırasıyla; $\% 80$ ve \%81) olmasına karşın pilorik atrezili ve kolonik atrezili tüm olgular hayatta kaldı. Ölen hastaların \%82'sinde (9/11) ek konjenital anomaliler vardı $\left(X^{2}=8,461, p=0,004\right)$. Bunlar majör kardiyak defektler $(n=3)$; Down sendromu $(n=2)$, biliyer atrezi $(n=1)$ ve özofagus atrezisi + trakeoözofageal fistül + anal atrezi + trakeal atrezi $(n=1)$, özofagus atrezisi + trakeoözofageal fistül $(n=1)$ ve mikrosefali $(n=1)$. Ek anomalisi olan ve olmayan hastaların ortalama hastanede kalıș süresi sırasıyla $26,4 \pm 21,4$ gün ve 23,04 $\pm 28,04$ gündü ( $p=0,207)$.

Sonuç: IA'lar arasında en sık duodenal atrezi, en az ise kolonik atrezi görüldü. Ek konjenital anomaliler İ'lı yenidoğanlarda hastanede kalış süresini ve mortalite oranını olumsuz etkilemektedir.

Anahtar Kelimeler: Intestinal atrezi, cerrahi tedavi, hastanede kalıs süresi, mortalite, yenidoğan
Address for Correspondence/Yazıșma Adresi: Tugay Tartar MD, Firat University Faculty of Medicine, Department of Pediatric Surgery, Elazı

Phone: +90 4242333555 E-mail: tugaytartar@gmail.com ORCID ID: orcid.org/0000-0002-7755-4736

Cite this article as/Atıf: Saraç M, Tartar T, Bakal Ü, Aydın M, Akdeniz I, Kazez A. Intestinal Atresia: Twenty Years of Experience at a Reference Hospital. İstanbul Med J 2021; 22(1): 19-24.
Received/Geliş Tarihi: 03.10.2019 Accepted/Kabul Tarihi: 26.11.2020

(C) Copyright 2021 by the University of Health Sciences Turkey, Istanbul Training and Research Hospital/istanbul Medical Journal published by Galenos Publishing House.

(C) Telif Hakkı 2021 Sağlık Bilimleri Üniversitesi Istanbul Ĕgitim ve Araştırma Hastanesi/Istanbul Tıp Dergisi, Galenos Yayınevi tarafından basılmıștır. 


\section{Introduction}

Intestinal atresia (IA) is one of the most common causes of intestinal obstruction in newborns. The IA incidence is 2.5-3 per 10,000 live births $(1,2)$. IA can be classified as follows. Type 1 cases have a transluminal septum accompanied by a proximal dilated bowel in continuity with a collapsed distal bowel (the bowel is usually of normal length). Type 2 refers to cases in which two blind-ending atretic ends are separated by a fibrous cord along the edge of an intact mesentery. Type 3A cases exhibit type 2 findings plus an additional mesenteric defect and a shortened bowel length, while type 3B cases have proximal jejunal atresia, often with malrotation, absence of most of the mesentery, and varying lengths of the ileum surviving after perfusion from the retrograde flow of a single supply artery. Type 4 refers to cases with multiple IAs of types 1, 2, and 3 in sequence (sausage appearance). However, in our study, we did not consider types 3A, B as separate entities; rather, we classified them together as type 3 IA (3). We used the expression "multiple IAs" for cases with more than one type of IA in different regions of the intestinal system.

Approximately 60 years ago, the mortality rate observed in newborns with IA was 30-50\%, whereas the current survival rates are $90 \%$ or higher (4-6). Advancements in newborn care, total parenteral nutrition (TPN), maternal polyhydramnios/antenatal diagnoses, neonatal anesthesia, and surgical techniques have resulted in higher survival rates among affected patients (2). However, some studies have reported survival rates of 41.7-71.5\% (7-9). Despite all efforts, newborns with IA still die due to additional congenital abnormalities, and those who survive may experience prolonged hospitalization due to the need for TPN and the presence of interfering infections.

The aims of this study were to determine the clinical and demographic characteristics of patients undergoing IA surgical treatment in a tertiary pediatric surgery and neonatal intensive care unit and to identify the factors affecting clinical outcome, as well as to share our experience.

\section{Methods}

The Fırat University Faculty of Medicine Ethics Committee approved the protocol before study initiation (approval number: 11, date: 16.11.2017). The study included pediatric patients undergoing surgical treatment for IA in the Pediatric Surgery and Newborn Intensive Care Unit of Firat University Faculty of Medicine between January 1997 and December 2016. We excluded the data from patients with esophageal atresia (EA) only or with isolated anal atresia. We extracted the data from patient files retrospectively. We recorded data such as gestational age, sex, birth weight, age at diagnosis, 5-minute Apgar score, maternal age, prenatal diagnosis, symptoms and findings, direct abdominal radiographic findings, IA site, presence of multiple IAs, concomitant intestinal/ systemic abnormalities, major cardiac defects, surgical technique, duration of hospital stay, short-term complications, clinical outcomes, and causes of mortality and morbidity. We compared the patient data according to the site of IA.

\section{Statistical Analysis}

For all statistical analyses, we used SPSS 21 for Windows (IBM SPSS Statistics, Armonk, NY, USA). Numerical variables are expressed as means \pm standard deviation and categorical variables as percentages (\%). We applied the Kruskal-Wallis test to compare variables with a non-normal distribution among more than two groups. We used the chi-square or Fisher's exact test to compare categorical variables. We evaluated binary categorical variables using the binomial test. We applied binary logistic regression to compare patients with and those without mortality. A p-value $<0.05$ was indicative of statistical significance.

\section{Results}

We evaluated 74 patients undergoing surgical treatment for IA. The newborn male to female ratio was 1.2. The mean age at diagnosis was $6.4 \pm 8.3$ days (range: $1-45$ days), the mean birth weight was $2.3 \pm 0.6 \mathrm{~kg}$, the mean gestational age was $35.6 \pm 2.79$ weeks, the mean maternal age was $28.9 \pm 6.1$ years, the mean hospital stay was $24.5 \pm 25.3$ days, and the mean 5-minute Apgar score was 7.6 \pm 1.7 . The IA site was classified as duodenal $(n=31,41.8 \%)$, jejunal $(n=17,22.9 \%)$, ileal $(n=15,20.2 \%)$, multiple $(n=5,6.7 \%)$, pyloric $(n=4,5.4 \%)$, or colonic $(n=2,2.7 \%)$. Table 1 presents the patient characteristics according to the site of the atresia. The most common site was the duodenum. The 5-minute Apgar scores, gestational ages, birth weights, hospital stay durations, and rates of maternal polyhydramnios, multiple IAs or additional intestinal/ systemic abnormalities, prematurity, sepsis, and mortality did not differ according to IA site $(p>0.05)$. The complication rate was significantly higher in patients with multiple IAs than in those with IA at other sites $(p=0.05)$.

Clinically, non-bilious vomiting was the most frequent complaint in patients with pyloric or duodenal atresia, whereas bilious vomiting/ nasogastric drainage was the most frequent complaint in all other patients. The most common physical examination finding was abdominal distension. Radiographic findings of the patients revealed massive gastric distension in all patients with pyloric atresia $(n=22$, $71 \%)$ and double-bubble signs $(n=8,26 \%)$ and free intraperitoneal air $(n=1,3.2 \%)$ in patients with duodenal atresia. Air-fluid levels $(n=15$, $88 \%)$, free intraperitoneal air $(n=1,6 \%)$, and ground glass appearance/ calcifications $(n=1,6 \%)$ were observed in patients with jejunal atresia. Of the 15 patients with ileal atresia, 11 (73\%) had air-fluid levels, and 3 (20\%) had intraperitoneal free air. The patient with ascending colonic atresia had intraperitoneal free air due to perforation. In addition, the patient with rectal atresia appeared to have a pouch colon. Four of the five (80\%) patients with multiple IAs had air-fluid levels, and the remaining one (20\%) had a massive gastric appearance.

The incidence of additional abnormalities was $68 \%$ in patients with duodenal atresia, $41 \%$ in patients with jejunal atresia, $24 \%$ in patients with ileal atresia, $80 \%$ in patients with multiple IAs, and $100 \%$ in patients with colonic atresia. Table 2 lists the additional abnormalities detected in the patients.

Mortality was observed in 4 of 33 (12\%) patients undergoing surgery within the first 2 days after birth and in 7 of 41 (17\%) patients undergoing surgery after more than 2 days; however, the difference was not statistically significant $(p=0.55)$. The complication and mortality rates in patients with type 4 IA (40\% and 20\%, respectively) were higher than 
those in patients with other types of IA. The survival rate of patients with pyloric atresia $(n=4)$ who underwent pyloroplasty and web excision was $100 \%$. The 31 patients with duodenal atresia underwent Kimura's diamond-shaped duodeno-duodenostomy $(n=24)$, duodenotomy + duodenal web excision $(n=6)$, or Kimura's diamond-shaped duodenoduodenostomy + gastrostomy $(n=1)$. The survival rate of the patients with duodenal atresia was $81 \%$. The 17 patients with jejunal atresia underwent resection anastomosis $(n=14)$, jejunostomy $(n=2)$, or resection anastomosis + gastroschisis repair with a prosthetic patch $(n=1)$. The survival rate of the patients with jejunal atresia was $88 \%$. The
15 patients with ileal atresia underwent resection anastomosis $(n=11)$, ileostomy $(n=3)$, or resection anastomosis with gastrostomy $(n=1)$. The survival rate of the patients with ileal atresia was $87 \%$. The two patients with colonic atresia underwent either resection anastomosis $(n=1)$ or resection anastomosis + colon pull-through $(n=1)$; both patients survived. The patients with multiple IAs $(n=5)$ underwent resection anastomosis $(n=4)$ or resection anastomosis + ileostomy $(n=1)$. Their survival rate was $80 \%$. Table 3 lists the surgical interventions performed on patients with IA, and Table 4 presents the postoperative complications and related treatments.

Table 1. Disease characteristics according to the site of the atresia

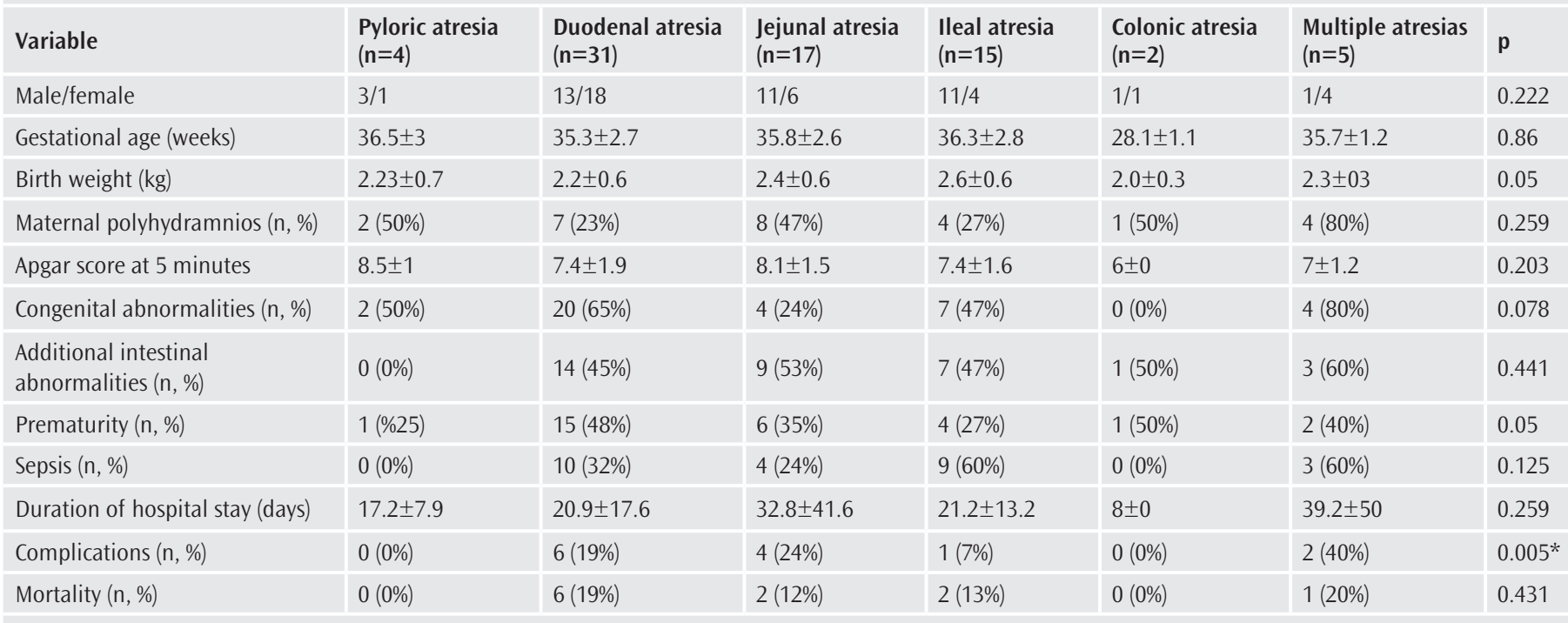

*The complication rate was statistically higher in the patients with multiple intestinal atresias

Table 2. Additional abnormalities detected in patients

\begin{tabular}{|c|c|c|c|c|c|}
\hline Type of atresia (n, \%) & $\begin{array}{l}\text { Duodenal atresia } \\
(n=31)\end{array}$ & $\begin{array}{l}\text { Jejunal atresia } \\
(n=17)\end{array}$ & $\begin{array}{l}\text { Ileal atresia } \\
(n=15)\end{array}$ & $\begin{array}{l}\text { Colonic atresia } \\
(n=2)\end{array}$ & $\begin{array}{l}\text { Multiple intestinal } \\
\text { atresias }(n=5)\end{array}$ \\
\hline Down syndrome & $10(32.2 \%)$ & $1(5.8 \%)$ & $2(13.3 \%)$ & - & $1(20 \%)$ \\
\hline Cardiac defect & $4(12.9 \%)$ & $2(11.7 \%)$ & $4(26.6 \%)$ & - & $2(40 \%)$ \\
\hline Esophageal atresia & $4(12.9 \%)$ & - & $1(6.6 \%)$ & - & - \\
\hline Anal atresia & $4(12.9 \%)$ & - & - & - & - \\
\hline Tracheal atresia & $1(3.2 \%)$ & - & - & - & - \\
\hline Biliary atresia & $1(3.2 \%)$ & - & - & - & - \\
\hline Gastroschisis & $1(3.2 \%)$ & $1(5.8 \%)$ & - & - & $1(20 \%)$ \\
\hline Choledochal cyst & $1(3.2 \%)$ & - & - & - & - \\
\hline Posterior urethral valve & - & - & $1(6.6 \%)$ & - & - \\
\hline Cleft palate & - & - & $1(6.6 \%)$ & - & - \\
\hline Intestinal perforation & $1(3.2 \%)^{*}$ & $2(11.7 \%)^{* *}$ & $3(20 \%)$ & $1(50 \%)$ & - \\
\hline Cystic fibrosis & $1(3.2 \%)$ & - & - & - & - \\
\hline Choanal atresia & - & $1(5.8 \%)$ & $1(6.6 \%)$ & - & - \\
\hline Hypothyroidism & $1(3.2 \%)$ & - & - & - & - \\
\hline Microcephaly & $1(3.2 \%)$ & - & - & - & - \\
\hline Pouch colon & - & - & - & $1(50 \%)$ & - \\
\hline Annular pancreas & $7(22.5 \%)$ & - & - & - & - \\
\hline Penoscrotal hypospadias & $1(3.2 \%)$ & - & - & - & - \\
\hline
\end{tabular}




\begin{tabular}{|l|l|l|}
\hline \multicolumn{2}{|l|}{ Table 3. Surgical procedures performed in patients } & with intestinal atresia \\
\hline Site of atresia & Number of patients & Primary operation \\
\hline Pyloric atresia & 4 & Pyloroplasty \\
\hline Duodenal atresia & 31 & $\begin{array}{l}\text { Duodeno-duodenostomy }(n=24) \text {, duodenal web excision ( } n=6) \text {, duodeno-duodenostomy + } \\
\text { gastrostomy }(n=1)\end{array}$ \\
\hline Jejunal atresia & 17 & Resection anastomosis $(n=14)$, resection anastomosis + silo formation $(n=1)$, jejunostomy $(n=2)$ \\
\hline Ileal atresia & 15 & Resection anastomosis $(n=11)$, resection anastomosis + gastrostomy $(n=1)$, ileostomy $(n=3)$ \\
\hline Colonic atresia & 2 & Resection anastomosis $(n=1)$, resection anastomosis + pull through $(n=1)$ \\
\hline Multiple intestinal atresias & 5 & Resection anastomosis $(n=4)$, resection anastomosis + ileostomy $(n=1)$ \\
\hline
\end{tabular}

\begin{tabular}{l|l|l|}
$\begin{array}{l}\text { Table 4. Postoperative complications and relevant treatment } \\
\text { options }\end{array}$ & $\begin{array}{l}\text { Number of } \\
\text { cases }\end{array}$ & Treatment \\
\hline Complications & 1 & Conservative therapy \\
\hline Wound infection & 2 & Resection anastomosis \\
\hline Anastomosis stenosis & 2 & Adhesiolysis \\
\hline Ileus & 1 & Tube thoracostomy \\
\hline Pneumothorax & 1 & Gastrostomy \\
\hline Gastric perforation & 2 & Total parenteral nutrition \\
\hline Short bowel syndrome & 2 & \\
\hline
\end{tabular}

The mean hospital stay duration was $17.2 \pm 7.9$ days (range: $9-25$ days) in patients with pyloric atresia, 20.9 \pm 17 days (range: $2-75$ days) in patients with duodenal atresia, 32.8 \pm 41.6 days (range: 7-180 days) in patients with jejunal atresia, 21.2 \pm 13.2 days (range: 8-50 days) in patients with ileal atresia, $8 \pm 0$ days in patients with colonic atresia, and $39.2 \pm 50$ days (range: 16-90 days) in patients with multiple IA. The longest hospital stay was observed in patients with jejunal atresia. Of the 11 patients who died, 9 (82\%) had additional congenital abnormalities $\left(X^{2}=8.461, p=0.004\right)$, which comprised major cardiac defects $(n=3)$, Down syndrome $(n=2)$, congenital biliary atresia $(n=1), E A+$ tracheoesophageal fistula (TEF) + anal atresia + tracheal atresia $(n=1), E A+\operatorname{TEF}(n=1)$, and microcephaly $(n=1)$. We found no independent effect of congenital abnormalities on patient mortality in our logistic regression analysis $\left(R^{2}=0.866, B=5.634\right.$, $\mathrm{SE}=4.161$, Wald=1.833, $\mathrm{df}=1, \mathrm{p}=0.176$, Exp B (95\% confidence interval, 279.7220 .80 to 974627.134$)$. The 5-minute Apgar score was $\leq 5$ in 5 (46\%) patients. The age at diagnosis was older than 2 days in 7 (63.6\%) patients, and the birth weight was $<2 \mathrm{~kg}$ in $5(45.5 \%)$ patients. The mean hospital stay of patients with and those without additional abnormalities were $26.4 \pm 21.4$ and $23.04 \pm 28.04$ days, respectively $(p=0.207)$.

\section{Discussion}

Duodenal atresia is more common in males than females. However, our series included 13 males and 18 females. Prenatal ultrasonography (US) can detect duodenal atresia better than jejunal, ileal, or colonic atresia. Basu and Burge (10) were able to diagnose 31\% of small IA cases by antenatal US. In our series, maternal polyhydramnios was detected in 7 of 31 patients with duodenal atresia (23\%) via prenatal US. Approximately $50 \%$ of the patients with duodenal atresia showed a double-bubble sign via direct abdominal radiography (11). The sign was present in 22 patients (71\%) in our series, of whom $26 \%$ had massive gastric appearance, and $3 \%$ had free intraperitoneal air.
Due to the high incidence of renal and cardiac abnormalities that accompany duodenal atresia, such cases should undergo echocardiography and abdominal US (2). Congenital abnormalities are present in more than $50 \%$ of patients with IA. In a series evaluated by Escobar et al. (12) that included 169 patients with duodenal atresia, the rate of Down syndrome was $27 \%$, that of maternal polyhydramnios was $33-50 \%$, and that of premature birth was $45 \%$. Congenital abnormalities were detected in $46 \%$ of the patients and included congenital cardiac diseases $(n=46), E A(n=14)$, anal atresia $(n=6)$, anal atresia $+E A(n=3)$, renal anomalies $(n=8)$, biliary atresia $(n=2)$, pyloric stenosis $(n=1)$, and Hirschprung's disease $(n=1)$. The incidence of additional abnormalities in the patients with duodenal atresia was $68 \%$ in our series, and these abnormalities included primarily Down syndrome (32.2\%), major cardiac defects (12.9\%), microcephaly (3.2\%), type 2 choledochal cyst (3.2\%), biliary atresia (3.2\%), gastroschisis (3.2\%), cystic fibrosis (3.2\%), penoscrotal hypospadias (3.2\%), anal atresia (9.6\%), EA + TEF (6.4\%), $\mathrm{EA}+\mathrm{TEF}+$ anal atresia (3.2\%), and EA + TEF + tracheal atresia (3.2\%). The most common surgical procedure used to treat duodenal atresia is Kimura's diamond-shaped duodeno-duodenostomy. Concomitant duodenectomy with web excision is a less frequent surgical technique used for cases of type 1 duodenal atresia due to the risk of damage to the ampulla vateri (2). Likewise, Kimura's diamond-shaped duodenoduodenostomy was performed in 24 patients in our series, duodenotomy + duodenal web excision in 6 patients, and Kimura's diamond-shaped duodeno-duodenostomy + gastrostomy in 1 patient. The mortality rate after duodenal obstruction have been reported at $9 \%$ by Rattan et al. (13), at $5.9 \%$ by Chen et al. (14), and at $58 \%$ by Zamir and Akhtar (15). In our series, the mortality rate was $19 \%$. Sepsis is the most important risk factor for duodenal atresia, with a mortality rate of 50\%. Congenital cardiac disease, prematurity, low birth weight, and Down syndrome are other risk factors (13). Sepsis (32\%), Down syndrome (32.2\%), prematurity (48\%), birth weight $<2 \mathrm{~kg}(48 \%)$, and major cardiac defects (12.9\%) were the most important underlying risk factors for mortality in our patients with duodenal atresia.

The incidence of jejunoileal atresia is approximately 1 in every 5000 live births, and this rate is similar between males and females. Approximately one-third of patients are born prematurely $(16,17)$. In our study, 11 males and 6 females had jejunal atresia, and 11 males and 4 females had ileal atresia. A premature birth history was observed in 35\% and $27 \%$ of the patients with jejunal and ileal atresia, respectively.

Advancements in newborn care, surgical techniques, TPN, antenatal diagnosis, and neonatal anesthesia have increased the survival rate 
of patients with IA from $80 \%$ in the 1990 s (16) to over $90 \%$ in the $21^{\text {st }}$ century $(18,19)$. The survival rates in our study $(100 \%$ in patients with pyloric atresia, $81 \%$ in those with duodenal atresia, $88 \%$ in those with jejunal atresia, $87 \%$ in those with ileal atresia, $100 \%$ in those with colonic atresia, and $80 \%$ in those with multiple IAs) were similar to those observed in the literature. The overall mortality rate was $14.9 \%$ in our study.

The surgical technique to be performed depends on the gastrointestinal system abnormalities and on the length of the intestine left behind, rather than the type of atresia itself. Whenever possible, wide resection of the proximal intestine and primary anastomosis are recommended with resection of the atretic segment (19). The expanded segment of the intestine of 3-25 cm was excised and anastomosed in our patients. The use of stomas is not recommended because it increases the risks of mortality and morbidity. The practice of stomas reduced from 20\% to as low as $10 \%$ from the 1970 s to 1990 s (6). In our series, a stoma was opened in only 7 patients with intestinal perforation (4.5\%).

Colonic atresia occurs in 1 in every 40,000 live births and constitutes approximately $1.8-15 \%$ of all IAs (20). In our study, colonic atresia was observed in 3 patients (4.1\%): isolated colonic atresia in 2 and multiple IAs in 1. In the literature, $47 \%$ of colonic atresia cases are accompanied by congenital abnormalities (21). In our series, we did not encounter additional congenital abnormalities in any of the patients with colonic atresia. The mortality rate of colonic atresia is reported to be $25.7 \%(21)$. However, none of the patients in our series died.

The mean hospital stay is reported to be 19 days in patients with duodenal atresia, 25 days in patients with jejunal/ileal atresia, and 12 days in patients with colonic atresia in the study by Piper et al. (22). In our study, the mean hospital stay was 21 days in patients with duodenal atresia, 33 days in those with jejunal atresia, 21 days in those with ileal atresia, 8 days in those with colonic atresia, and 39 days in those with multiple IAs.

Early diagnosis and treatment are thought to reduce the mortality of patients with IA $(23,24)$. In our series, 4 of $33(12 \%)$ patients undergoing surgery within the first 2 days died, whereas 7 of 41 (17\%) undergoing surgery after 2 days died; however, the difference was not significant. In patients with IA, the abdominal re-operation rates vary between $14 \%$ and $25 \%$ for postoperative complications $(22,25)$. In our series, the rate of abdominal reoperation was $4 \%$ for postoperative complications.

\section{Conclusion}

The mean hospital stay in our study was similar to those reported in the literature. Although the mortality rates of patients with multiple and duodenal atresias were consistent with those in the literature, we encountered no deaths in patients with pylorus or colonic atresia. Concomitant severe congenital abnormalities in these patients adversely affect the hospital stay and mortality rate.

\section{Ethics}

Ethics Committee Approval: The Fırat University Faculty of Medicine Ethics Committee approved the protocol before study initiation (approval number: 11, date: 16.11.2017).
Informed Consent: Retrospective study.

Peer-review: Externally and internally peer-reviewed.

Authorship Contributions: Surgical and Medical Practices - M.S., T.T., Ü.B., A.K.; Concept - M.S., T.T., Ü.B.; Design - M.S., T.T., M.A.; Data Collection or Processing - T.T., Ü.B., I.A.; Analysis or Interpretation - Ü.B., M.A., I.A., A.K.; Literature Search - M.S., M.A., I.A., A.K.; Writing - M.S., T.T., M.A., A.K.

Conflict of Interest: No conflict of interest was declared by the authors.

Financial Disclosure: The authors declared that this study received no financial support.

\section{References}

1. Forrester MB, Merz RD. Population-based study of small intestinal atresia and stenosis, Hawaii, 1986-2000. Public Health 2004; 118: 434-8.

2. Grosfeld JL, Ballantine TV, Shoemaker R. Operative management of intestinal atresia and stenosis based on pathologic findings. J Pediatr Surg 1979; 14 : 368-75.

3. Gupta S, Gupta R, Ghosh S, Gupta AK, Shukla A, Chaturvedi V, et al. Intestinal atresia: experience at a busy center of North-West India. J Neonatal Surg 2016; 5: 51.

4. Gross RE. Congenital atresia of the intestine and colon. In: Gross RE, editor. The Surgery of Infancy and Childhood: Its Principles and Techniques. Philadelphia (PA): WB Saunders; 1953. p. 150-66.

5. Akkoyun I, Erdoğan D, Cavuşoğlu YH, Tütün O. What is our development progress for the treatment outcome of newborn with intestinal atresia and stenosis in a period of 28 years? N Am J Med Sci 2013; 5: 145-8.

6. Kumaran N, Shankar KR, Lloyd DA, Losty PD. Trends in the Management and Outcome of Jejuno-Ileal Atresia. Eur J Pediatr Surg 2002; 12: 163-7.

7. Chirdan LB, Uba AF, Pam SD. Intestinal atresia: management problems in a developing country. Pediatr Surg Int 2004; 20: 834-7.

8. Ekenze SO, Ibeziako SN, Ezomike UO. Trends in neonatal intestinal obstruction in a developing country, 1996-2005. World J Surg 2007; 31: 2405-9.

9. Chadha R, Sharma A, Roychoudhury S, Bagga D. Treatment strategies in the management of jejunoileal and colonic atresia. J Indian Assoc Pediatr Surg 2006; 11: 79-84.

10. Basu R, Burge DM. The effect of antenatal diagnosis on the management of small bowel atresia. Pediatr Surg Int 2004; 20: 177-9.

11. Nijs E, Callahan MJ, Taylor GA. Disorders of the pediatric pancreas: imaging features. Pediatr Radiol 2005; 35: 358-73.

12. Escobar MA, Ladd AP, Grosfeld JL, West KW, Rescorla FJ, Scherer LR 3rd, et al. Duodenal atresia and stenosis: long-term follow-up over 30 years. J Pediatr Surg 2004; 39: 867-71.

13. Rattan KN, Singh J, Dalal P. Neonatal duodenal obstruction: A 15-year experience. J Neonatal Surg 2016; 5: 13.

14. Chen QJ, Gao ZG, Tou JF, Qian YZ, Li MJ, Xiong QX, et al. Congenital duodenal obstruction in neonates: a decade's experience from one center. World J Pediatr 2014; 10: 238-44

15. Zamir N, Akhtar J. Neonatal duodenal obstruction: clinical presentation and outcome. J Surg Pakistan (Int) 2013; 18: 182-5.

16. Bodian M, White LLR, Carter CO, Louw JH. Congenital duodenal obstruction and mongolism. Br Med J 1952; 1: 77-9.

17. Dalla Vecchia LK, Grosfeld JL, West KW, Rescorla FJ, Scherer LR, Engum SA. Intestinal atresia and stenosis: a 25-year experience with 277 cases. Arch Surg 1998; 133: 490-6. 
18. Walker K, Badawi N, Hamid CH, Vora A, Halliday R, Taylor C, et al. Neonatal Intensive Care Units' (NICUS) Group, NSW Pregnancy and Newborn Services Network. A population-based study of the outcome after small bowel atresia/ stenosis in New South Wales and the Australian Capital Territory, Australia, 1992-2003. J Pediatr Surg 2008; 43: 484-8.

19. Stollman TH, de Blaauw I, Wijnen MH, van der Staak FH, Rieu PN, Draaisma JM, et al. Decreased mortality but increased morbidity in neonates with jejunoileal atresia; a study of 114 cases over a 34-year period. J Pediatr Surg 2009; 44: 217-21.

20. Singh V, Pathak M. Congenital neonatal intestinal obstruction: retrospective analysis at tertiary care hospital. J Neonatal Surg 2016; 5: 49.
21. Etensel B, Temir G, Karkiner A, Melek M, Edirne Y, Karaca I, et al. Atresia of the colon. J Pediatr Surg 2005; 40: 1258-68.

22. Piper HG, Alesbury J, Waterford SD, Zurakowski D, Jaksic T. Intestinal atresia: factors affecting clinical outcomes. J Pediatr Surg 2008; 43: 1244-8.

23. Stoll C, Alembik Y, Dott B, Roth MP. Evaluation of prenatal diagnosis of congenital gastro-intestinal atresia. Eur J Epidemiol 1996; 12: 611-6.

24. Miro J, Bard H. Congenital atresia and stenosis of the duodenum: the impact of a prenatal diagnosis. Am J Obstet Gynecol 1988; 158: 555-9.

25. Calisti A, Olivieri C, Coletta R, Briganti V, Oriolo L, Giannino G. Jejunoileal atresia: factors affecting the outcome and long-term sequelae. J Clin Neonatol 2012; 1: 38-41. 